\title{
The Need for Emotional Intelligence Skills among Knowledge Workers at the Tertiary Level
}

\author{
Mary Thomas, Peter Francis, Siti Asiah Md. Shahid, and Syahrina Hayati Md. Jani
}

\begin{abstract}
The concept of emotional intelligence is gaining more importance in academic settings as it is believed that educators who can regulate their emotions positively will be more effective lecturers, generating a positive teaching and learning environment Thus, this study explores the level of agreement on the four components of emotional intelligence skills among lecturers in public and private universities in Perak, Malaysia The research methodology used a descriptivesurvey of the exploratory type involving 275 permanent lecturers from the selected universities chosen through simple random sampling. The survey instrument for this study is a set of questionnaire which is an adapted version of the items in the Emotional Skills Assessment Process (ESAP) combined with the elements of the knowledge workers and self-evaluation of teaching effectiveness (SETE).Findings revealed that the highest mean on the level of agreement for emotional intelligence from both types of institutions was for the emotional intelligence component of self-management skills while the lowest mean was recorded for the component of intrapersonal skills.
\end{abstract}

Index Terms-Emotional intelligence, knowledge workers, lecturers, teaching effectiveness.

\section{INTRODUCTION}

In this contemporary era, the development in the areas of science and technology has paved the way for the rise of a knowledge-based economy. The idea of knowledge workers is gaining more significance in the workplace as a welleducated and skilled workforce is crucial to increase work efficiency and performance. It is Malaysia's vision to become an industrialized nation by the year 2020 and Malaysian universities are entrusted with the task of producing workforce that meets the demands of the nation. This means that institutions of higher learning have to work hand in hand with the government to boost economic growth of the nation.

One aspect of quality that is vital in educational institutions is the quality of its knowledge workers, specifically the teaching staff as it is they who are responsible for imparting education and knowledge which in turn builds up and shapes the economic stability and the development of society.

Manuscript received November 25, 2013; revised January 29, 2014. This work was supported in part by the KPERAK Implementation and Coordination Corporation, Malaysia under Grant No. RD0002.

The authors are with the Academy of Language Studies at Universiti Teknologi Mara (Perak), Kampus Seri Iskandar, 32610 Bandar Seri Iskandar, Perak, Malaysia (e-mail: maryt414@perak.uitm.edu.my, peter034@perak.uitm.edu.my, syahr520@perak.uitm.edu.my).
According to [1] "the Malaysian government regards highly skilled human capital as the nucleus of a knowledgebased economy". He further adds that in the past, the Malaysian public universities were traditionally restricted to the elite but as there was a need to quicken the pace of transformation from "a labour-intensive and lower-end manufactured products to an economy based on knowledge", there emerged more private universities. However, the main goal of all tertiary institutions in Malaysia, whether public or private, is to produce high quality graduates who can fulfill the needs of the industry.

In an article by [2] on the readiness of higher education institutions in Malaysia towards a knowledge based economy, it was reported that the nation was still deficient in many of the pre-requisites for the k-economy as indicated by the knowledge-based Economy Development Index (KDI). They recommended that higher educational institutions should have a suitable mix in the level of qualification and area of specialization and ensure that quality education and training is delivered. In addition, higher education institutions have to be prepared for changes to fulfill the new requirements and challenges from both the industry and society.

Currently, the teaching environment within universities in Malaysia is very challenging due to the increasing standard and expectation of education within the nation. Lecturers are expected to take on multiple roles and tasks such as conducting research, publishing material, presenting papers, and engaging with students and community service activities [3]. These roles are crucial as research is considered the key for knowledge creation and knowledge dissemination. In short, it is time for the higher learning institutions in the nation to adapt to their changing roles in a knowledge-based society. Although there is a rapid move towards research and development, lecturers are also expected to be effective in their teaching methods. The teaching and learning process is crucial to institutions of higher learning as the outcomes attained by their learners manifest the standard of the educational institution within the industry. The ability to integrate all these aspects in their role as lecturers and to develop professionally in their career at the same time require educators to possess the skills of emotional intelligence.

In the university context, there is consensus that university tasks undertaken by knowledge workers run on brain power but there is added evidence by [4] that emotion is the necessary "fuel" for the brain's higher reasoning powers. Hence, emotional intelligence is increasingly viewed as an ingredient that contributes to the effectiveness of instructors. 


\section{LITERATURE REVIEW}

\section{A. Emotional Intelligence}

According to [5], the emergence of literature in emotional intelligence began with psychological research in two main areas namely cognition and affect and the evolution in models of intelligence. The first area focused on the interaction between cognitive and emotional processes to enhance thinking while the second area focused on the models of intelligence. This evolution of models of intelligence began by incorporating the multiple intelligences as proposed by [6] which focused not only on mental abilities but also those that dealt with the emotional aspects like intra-personal and interpersonal skills. The term emotional intelligence became even more popular with the publication of the book by [7] entitled, Emotional Intelligence: Why it can matter more than IQ. In his book he emphasizes that IQ only accounts for about $20 \%$ of an individual's success and implies that emotional intelligence is a key ingredient of success. The models of emotional intelligence can be summarized and synthesized into two major types namely; the ability model and the mixed model.

The emotional intelligence skills used were according to the Emotional Skills Assessment Process (ESAP), which involved interpersonal skills, personal leadership skills, selfmanagement skills, and intrapersonal skills [8].

\section{B. Models of Emotional Intelligence}

Ref. [9] initially coined the term emotional intelligence or emotional quotient to represent the ability which enables an individual " to monitor one's own feelings and emotions, to discriminate among them and to use this information to guide one's thinking and actions". They perceive emotional intelligence as a pure intelligence which requires individuals to use their mental abilities to understand emotions. Hence, this model by [10] began to be considered as ability based model and was based on a scientific approach to explain the term emotional intelligence. The four basic skills of EI as described by [10] are the "ability to accurately perceive, appraise, and express emotions; the ability to access and/or generate feelings that facilitate thinking; the ability to understand emotions and to utilize emotional knowledge, and the ability to regulate emotions to promote emotional and intellectual growth". The four branch model according to them creates intelligence with emotion and all the four branches are requirements to label a person as emotionally intelligent.

Ref. [7] went on to expand the original works of [9] and defined emotional intelligence as "knowing what one's feelings are and using that knowledge to make good decisions". The definition of EI by [7] includes five domains similar to that mentioned by [10] but with slight variations to the terms. The five components of EI as mentioned by [7] are 'self-awareness', 'self-regulation', 'motivation', 'empathy' and 'adeptness in relationships'. The model by [7] began to be referred to as a competency model or mixed model as it includes emotions, skills and abilities as a larger competency.

Ref. [11] characterizes emotional intelligence as "an array of non-cognitive capabilities, competencies, and skills that influence one's ability to succeed in coping with environmental demands and pressures" His model similar to the model by [7] is a mixed model of emotional intelligence which includes five broad areas of skills or competencies: intrapersonal EQ, interpersonal EQ, adaptability EQ, stress management EQ, and general mood EQ [11].

Ref. [8] suggested that emotional intelligence is the result ofboth the rational and emotional minds. [8] describe emotional intelligence as " a confluence of developed skills and abilities to: (1) accurately know yourself in terms of personal strengths and weaknesses, (2) establish and maintain effective relationships, (3) get along and work productively with others and (4) deal effectively and healthily with the demands and pressures of daily living". They further add that EI is a learned ability to identify experience, understand, and express emotions in healthy and productive ways. [8] developed their first instrument in 1998 which was referred to as Exploring and Developing Emotional Intelligence Skills (EDEIS) but this instrument is now commonly called the Emotional Skills Assessment Process (ESAP) [8].

\section{Emotional Skills Assessment Process (ESAP)}

It is an instrument that was developed specifically for use in educational settings. The ESAP is divided into four specific domains as follows: "1) interpersonal communication under stress, including assertion, aggression and deference; 2) personal leadership skills, including comfort, empathy, decision-making and leadership; 3) selfmanagement in life and career, including drive strength, time-management, commitment ethic, and change orientation, and 4) intrapersonal skills, including self-esteem, and stress management" [8].

Interpersonal skills deal specifically with communication skills. These skills are crucial for lecturers as they need to interact not only with students but also with peers, parents, and administrators [12]. Personal Leadership Skills are also crucial to lecturers as they are required to be good role models for their students. Possessing good leadership competencies enable lecturers to achieve a higher job performance and establish a conducive learning environment [13] .Self-management skills are also important for lecturers as the teaching environment in universities is getting more challenging with lecturers having to perform multiple tasks [3]. If lecturers do not possess the elements of commitment ethic, drive strength and time-management, they will not be able to perform all their tasks responsibly [8]. The final component of ESAP deals with intrapersonal skills which include the elements of self-esteem and stress management [8]. These skills are also crucial for lecturers to ensure that they believe in their selfworth and do not succumb to stress and anxiety which can lead them into job burnout.

\section{RESEARCH OBJECTIVE}

The main goal of this study is to identify the level of agreement on the four components of emotional intelligence skills among lecturers in public and private university.

\section{RESEARCH METHODOLOGY}

The research methodology used a descriptive-survey of 
the exploratory type involving 275 permanent lecturers from the selected universities in Perak, Malaysia chosen through simple random sampling.

In relation to education level of the respondents it ranged from Bachelors Degree to $\mathrm{PhD}$. The biggest proportion of respondents held a Masters Degree (59.3\%) as it is the entry requirement for the position of lecturers is Masters for most of the public and private universities. 8 percent of the respondents held a Bachelors Degree while 32.7 percent possessed a $\mathrm{PhD}$ qualification. Most of the respondents were female $(52.4 \%)$ while only $47.6 \%$ of the respondents were male. The number of respondents in public University A was $71(25.8 \%)$ and in public University B was 99 $(36.0 \%)$. Meanwhile the respondents for private University C amounted to $55(20.0 \%)$ and private University D was 50 (18.2\%). The number of respondents from University B was the highest as university B had more number of faculties in comparison to other universities in this study. The age group of the respondents range from 30 years and below to 56 years and above. Most of the respondents were in the age category of 30 years and below $(27.3 \%)$, and the smallest proportion of respondents was from the age group of 56 years and above $(4.7 \%)$. Most of the respondents had been working with their organization for 5 years or less than 5 years $(43.6 \%)$ which comprised a younger generation of the teaching force.

The survey instrument for this study is a set of questionnaire which is an adapted version of the items in the Emotional Skills Assessment Process (ESAP) combined with the elements of the knowledge workers and selfevaluation of teaching effectiveness (SETE). The ESAP includes the four components of emotional intelligence mainly interpersonal skills, personal leadership skills, self management skills and intrapersonel skills. The SETE instrument was designed to analyse five elements of teaching effectiveness which include analytical approach, clarity of teaching, lecturer-group interaction, lecturerindividual student interaction and enthusiasm of lecturer. The reliabilty of the questionnaire was assessed by calculating the Cronbach alpha through the Statistical Package for Social Science (SPSS) version 20. The Cronbach alpha for both the ESAP and SETE recorded a high reliability value of 0.815 and 0.914 respectively.

\section{FINDINGS}

Descriptive statistics was used to analyse the data by calculating the mean scores and standard deviations of each the variables of emotional intelligence components which comprise interpersonal, personal leadership, selfmanagement and intrapersonal skills.

\section{A. Perception Level of Agreement of the Four Components of Overall Emotional Intelligence by Lecturers}

The mean scores in Table I shows that the highest perception level of agreement for lecturers was selfmanagement $(M=3.98, S D=0.42)$ followed by personal leadership $(M=3.87, S D=0.43)$. The lowest mean was intrapersonal $(M=3.56, S D=0.40)$. Based on Table II it can be concluded that the lecturers were in the moderate level of agreement in interpersonal and intrapersonal components of emotional intelligence, while personal leadership and self-management was reported to be in the high level of agreement of emotional intelligence components.

TABLE I: MEAN SCORES AND STANDARD DEVIATIONS OF THE FOUR COMPONENTS OF EMOTIONAL INTELLIGENCE

\begin{tabular}{lll}
\hline \multicolumn{1}{c}{ Variables } & $\mathrm{M}$ & $\mathrm{SD}$ \\
\hline Interpersonal & 3.62 & 0.51 \\
Personal Leadership & 3.87 & 0.43 \\
Self-Management & 3.98 & 0.42 \\
Intrapersonal & 3.56 & 0.50 \\
\hline \hline
\end{tabular}

TABLE II: LEVELS OF AGREEMENT OF EMOTIONAL INTELLIGENCE COMPONENTS BY LECTURERS

\begin{tabular}{lc}
\hline \hline Level & Scale \\
\hline Low & $1.00-2.33$ \\
Moderate & $2.34-3.67$ \\
High & $3.68-5.00$ \\
\hline \hline
\end{tabular}

\section{B. Perception Level of Agreement of the Four Components of Emotional Intelligence by Lecturers in Public Universities}

The results in Table III shows that the highest perception level of agreement for lecturers was self-management $(M=$ $3.98, S D=0.39)$. Next highest was personal leadership $(M=$ $3.84, S D=41)$, and the lowest mean was intrapersonal $(M=$ $3.48, S D=0.46)$. From Table III, it can be concluded that the lecturers were in the moderate level of agreement in interpersonal and intrapersonal, and high level of agreement in personal leadership and self-management.

TABLE III: MEAN SCORES AND STANDARD DEVIATIONS OF THE FOUR COMPONENTS OF EMOTIONAL INTELLIGENCE IN PUBLIC UNIVERSITIES

\begin{tabular}{lll}
\hline \hline \multicolumn{1}{c}{ Variables } & $\mathrm{M}$ & $\mathrm{SD}$ \\
\hline Interpersonal & 3.57 & 0.50 \\
Personal Leadership & 3.84 & 0.41 \\
Self-Management & 3.98 & 0.39 \\
Intrapersonal & 3.48 & 0.46 \\
\hline \hline
\end{tabular}

C. Perception Level of Agreement of the Four

Components of Emotional Intelligence by Lecturers in Private Universities

TABLE IV: MEAN SCORES AND STANDARD DEVIATIONS OF THE FOUR COMPONENTS OF EMOTIONAL INTELLIGENCE IN PRIVATE UNIVERSITIES

\begin{tabular}{lll}
\hline \hline \multicolumn{1}{c}{ Variables } & $\mathrm{M}$ & $\mathrm{SD}$ \\
\hline Interpersonal & 3.70 & 0.52 \\
Personal Leadership & 3.93 & 0.46 \\
Self-Management & 4.09 & 0.45 \\
Intrapersonal & 3.69 & 0.54 \\
\hline \hline
\end{tabular}

As reported in Table IV the highest perception level of agreement for lecturers was self-management $(M=4.09, S D$ $=45)$. This is followed by personal leadership $(M=3.93$, 
$S D=0.46)$, and the lowest mean was intrapersonal $(M=$ $3.69, S D=0.54)$. From Table IV it can be concluded that the lecturers were in the moderate level of agreement in interpersonal and intrapersonal, and high level of agreement in personal leadership and self-management.

\section{DISCUSSION}

The productivity of knowledge workers is important to an organization specifically in this current era. Hence, lecturers who are knowledge workers must be experts in teaching because teaching is the core business of lecturers. Besides teaching, they must also be involved in research activities, attending and presenting their research findings in conferences, networking and linkages, and supervision [3]. In other words, they must be good in both hard and soft skills [14]

Research by [15] on the emotional intelligence of Malaysian teachers and its implication on workplace productivity found that teachers with high self-awareness skills also possessed high self-regulation skills. Hence, such teachers would constantly reflect on the strengths and weaknesses of their teaching and work towards managing and improving the aspects that they lack. This indicates that emotional intelligence is a crucial ingredient in the teaching and learning process as "the task of creating environment conducive to learning rests heavily on the talents and self efficacy of teachers" [16]. In the case of lecturers, the multiple tasks expected of them besides teaching is an additional pressure which they have to deal with effectively without suffering from burnout. Possesing a high emotional intelligence skills will ensure that they will be able to cope with such pressure and perform their routine tasks effectively.

Based on the result of this study on the level of agreement of overall emotional intelligence skills for both private and public universities indicate a high score in overall emotional intelligence skills for the components of self-management and personal leadership. However, the components of interpersonal and intrapersonal skills recorded a moderate level of agreement.

Based on the comparison on the level of agreement for all emotional intelligence components between the two types of institutions revealed that in public universities only two emotional intelligence skills components which is selfmanagement and personal leadership recorded a high level of agreement. The components of intrapersonal and interpersonal skills only indicated a moderate level of agreement. The implication of this finding is that there is a need for lecturers in public universities to have a greater awareness of their personal strengths and weaknesses so that they can progress in becoming more confident individuals. There is also a need to improve communication skills to enable them to maintain healthy interpersonal relationships.

In contrast, private universities scored a high level of agreement in all of the four components of emotional intelligence with self-management skills recording the highest overall mean scores. This indicates that knowledge workers in private institutions have a reasonably higher level of self-regulation skills. This could be the result of the highly competitive environment of private institutions which require a high drive and commitment to be successful at the workplace and personal career.

\section{CONCLUSION}

In conclusion, to be productive knowledge workers, lecturers must learn how to utilize their emotions effectively so that they can be more successful at the workplace and in life.

\section{REFERENCES}

[1] A. Kamogawa, "Higher education reform: Challenges towards a Knowledge Society in Malaysia. African and Asian studies," Koninklijke Brill NV, Leiden, vol. 2, no. 4, pp. 545-563, 2003.

[2] I. Mazharul and H. C. Eaw, "The readiness of higher education institutions (HEIs) towards knowledge-based economy in Malaysia,' International Review of Business Research Papers, vol. 4 no. 2, pp. 103-11, 2008.

[3] Iskandar, M. M. Rohaty, and M. Zuria, "Kecerdasan emosi dan komitmen pekerjaan dalam kalangan pensyarah universiti di Indonesia (Emotional quotient and work commitment among lecturers at an Indonesian university," Jurnal Pendidikan (UKM), vol 34 , no. 1, pp. 173-186, 2009.

[4] R. K. Cooper and A. Sawaf, Executive EQ: Emotional Intelligence in Leadership and Organizations, Grosset/Putnam, New York, NY. 1997.

[5] M. A. Brackett, S. E. Rivers, and P. Salovey, "Emotional intelligence: Implications for personal, social, academic, and workplace success," Social and Personality Psychology Compass S/1, pp. 88-103, 2011.

[6] H. Gardner, Frames of Mind: The Theory Of Multiple Intelligences, $2^{\text {nd }}$ ed., York: Basic Books, 1993.

[7] D. Goleman, Emotional Intelligence: Why It Can Matter More Than $I Q$, Bantam Books, New York, 1995.

[8] D. B. Nelson and G. R. Low, Emotional intelligence: Achieving academic and career excellence, $2^{\text {nd }}$ ed., New York: Prentice Hall, 2003, pp. 9-13.

[9] J. D. Mayer and P. Salovey, "Emotional intelligence," Imagination, Cognition and Personality, vol. 9, no. 3, pp. 185-211, 1990.

[10] P. Salovey and J. D. Mayer, "What is emotional intelligence?" in Emotional Development, Emotional Literacy, and Emotional Intelligence, P. Salovey and D. Sluyter Eds. New York: Basic Books, 1997.

[11] R. Bar-On, The Emotional Quotient Inventory (EQ-i): A Test of Emotional Intelligence, Toronto: Multi-Health Systems, 1997.

[12] Teacher Education Handbook, West Virginia University Parkersburg, 2009, pp. 2.

[13] M. J. S. Hayati, "The relationship between emotional intelligence and teaching effectiveness among lecturers at Universiti Teknologi MARA, Puncak Alam, Selangor," Masters Thesis, Universit Teknologi MARA, Shah Alam, Selangor, 2011.

[14] M. S. S. Asiah, "A study of perceived leadership soft skills, trustworthiness and structural empowerment of deans in three Malaysian Public Universities," Ph.D thesis, Universiti Sains Malaysia, Minden, Malaysia, 2011

[15] M. R. Noriah, M. M. Zuria, and R. A. Siti, "Emotional intelligence of Malaysian teachers: Implications on workplace productivity," International Journal of Vocational Education and Training, vol. 14, no. 2, pp. 7-24, 2006.

[16] A. Bandura, Self-efficacy in Changing Societies, Cambridge: Cambridge University Press, 1995.

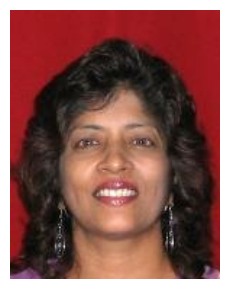

Mary Thomas was born on 20 March 1964 in Slim River, Perak, Mary Thomas did her early and secondary education in Selangor. She holds a bachelor of arts (hons) and a diploma in Education from Universiti Kebangsaan Malaysia, Malaysia which was obtained in 1989 and 1990 respectively. She also has a masters degree in teaching of English to Speakers of Other languages (MSc. TESOL) from the University of Stirling, Scotland obtained in 1996.

She is currently pursing a doctorate degree with Universiti Putra Malaysia.

She is a senior lecturer with the the academy of Language Studies, Universiti Teknologi Mara(UiTM), Perak, Malaysia and has also served as 
the tesl coordinator of this institution She has taught ESL in UiTM for over 23 years. She has written and presented papers on learning styles and strategies, autonomous learning, communication apprehension and emotional intelligence. Her current research includes a study on the relationship between knowledge workers and teaching effectiveness among university lecturers in Perak and on the relationship between emotional intelligence and oral communication apprehension and skills among tertiary learners.

Ms. Thomas is a life time member of Malaysian English Language Teaching Association (MELTA) and ASIA-TEFL member since 2010.

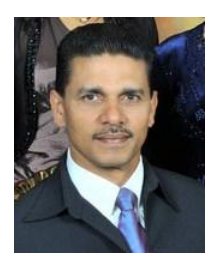

Peter Francis was born on 16 June 1964 in Sitiawan, Perak, Peter Francis did his early and secondary education in Perak. He holds a Diploma in ESL from Universiti Malaya in 1996 and a bachelor of edaucation in tesl from Universiti Putra Malaysia, Malaysia which was obtained in 2000. He also graduated with a masters of science degree in teaching of English as a Second Language. (MSc. TESL) from Universiti Putra Malaysia, Malaysia in 2002.

$\mathrm{He}$ is a senior lecturer with the the Academy of Language Studies, Universiti Teknologi Mara(UiTM), Perak, Malaysia.He has taught ESL in UiTM for over 11 years. Prior to his employment at UiTM, he served as a teacher for 13 years teaching English in schools both at the primary and secondary level. He has written and presented papers on learning styles and strategies, autonomous learning, and using literature in the ESL classroom.

His current research includes a study on the relationship between knowledge workers and teaching effectiveness among university lecturers in Perak and on the relationship between emotional intelligence and oral communication skills among tertiary learners.

Mr. Francis is a life time member of Malaysian English Language Teaching Association (MELTA) and ASIA-TEFL member since 2010.

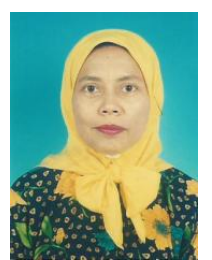

Siti Asiah Md. Shahid holds a diploma in stenography from Institut Teknologi Mara, Dungun, Terengganu, Malaysia which was obtained in 1986. She also obtained her bachelor of education from The University of Toledo, Toledo, Ohio, USA, majoring in business education in 1995; MSc in Education from Virginia Polytechnic Institute and State University, Blacksburg, Virginia, USA, majoring in vocational and technical education in 1997; and PhD from Universiti Sains Malaysia, Penang, Malaysia, majoring in Educational Leadership and Management in 2011.

She is a senior lecturer at the Faculty of Business Management, Universiti Teknologi Mara, Perak, Malaysia and has also served as head of institute education Development of this institution. She has taught business management subjects including Administrative Office Management, Human Resource Management and Organizational Behaviour and has served this institution for 26 years. She has written and presented papers on leadership and soft skills.

Her current research includes a study on the relationship between knowledge workers and teaching effectiveness among university lecturers in Perak. Her research fields include leadership soft skills; soft skills in higher education; emotional intelligence; organizational behavior; business and office management and human resource management.

Dr. Siti Asiah Md. Shahid is a lifetime member of Golden Key National Honor Society, USA and also a member of Mara Institute of Technology Academic Staff Association (MITASA), Malaysia

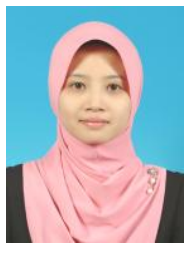

Syahrina Hayati Md. Jani was born on 19 May 1982 in Muar, Johor, Syahrina Hayati did her early and secondary education in Melaka. In year 2000, she gained admission into Universiti Teknologi MARA in Shah Alam, Selangor. She first enrolled for a diploma in office management and technology and later in 2006 went on to pursue a bachelor degree in office systems management.

She worked at Jensepadu Sdn. Bhd. as a personal assistant in Klang, Selangor for a year. She then joined Cosmopoint International College of Technology (CICT) as a lecturer she then pursued a masters' degree under the young lecturer's scheme and successfully completed her masters in office systems management in 2011. Currently, she works as a lecturer at the faculty of Business Management, Universiti Teknologi Mara (Perak), Kampus Seri Iskandar, Bandar Seri Iskandar, Perak Darul Ridzuan.

In UiTM (Perak), Ms. Syahrina Hayati has joined the lead scholar group which is an initiative group that is involved in research work. Now, she works together with a group of colleagues to provide consultancy services to KPERAK Implementation and Coordination Corporation. 